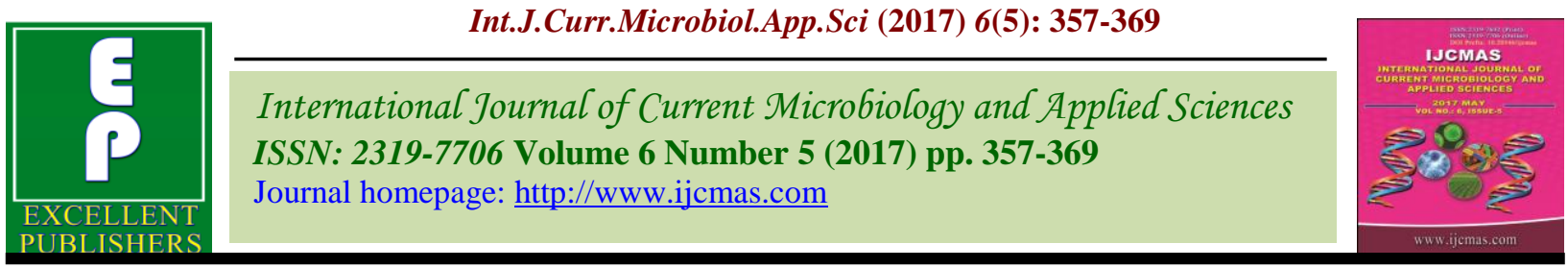

Original Research Article

https://doi.org/10.20546/ijcmas.2017.605.041

\title{
Effect of Stressors on Haematological and Hormonal Parameters of Garra gotyla gotyla
}

\author{
Jyoti Sharma $^{1 *}$, Shabir Ahmed Dar ${ }^{2}$, A.N. Sayani ${ }^{3}$ and Seema Langer ${ }^{4}$ \\ ${ }^{1}$ Government Degree College, Kathua, J\&K, India \\ ${ }^{2}$ Government Degree College, Baramulla, Jammu and Kashmir- 193 103, India \\ ${ }^{3}$ College of Fisheries, Junagadh Agricultural University, Veraval, Gujarat- 362 265, India \\ ${ }^{4}$ Department of Zoology, University of Jammu-181 101, India \\ *Corresponding author
}

\begin{abstract}
Ke y w o r d s
Stress, Natural, Anthropogenic, Haematology, Hormones, Garra gotyla gotyla. been made to study the effect of stressors natural (Starvation) and anthropogenic (Manganese) on haematological [Total erythrocyte count (TEC), Haemoglobin ( $\mathrm{Hb}$ ), Haematocrit (Hct), Total leucocyte count (TLC) and Differential leucocyte count (DLC)] and hormonal (Cortisol and Glucose) parameters of fish, Garra gotyla gotyla for an experimental period of 9 weeks. Under the effect of natural stressor, starved fishes were found to exhibit significant decline in TEC, Hb, Hct and TLC. DLC when viewed revealed a decrease in lymphocytes, monocytes, eosinophils and basophils whereas neutrophils and thrombocytes rather exhibited an appreciable increase. A significant increase $(\mathrm{P}<0.01)$ in cortisol and glucose levels were observed up to $5^{\text {th }}$ week and here after a significant decline was noticed during rest period of experimental duration. Garra gotyla gotyla also depicted significant decline in TEC, $\mathrm{Hb}$ and Hct under the effect of manganese toxicity $\left(\mathrm{MnSO}_{4}-1.96 \mathrm{mg} / \mathrm{l}\right)$. Contrary to RBC dependent parameters (TEC, Hb and Hct) TLC depicted significant increase and among Differential leucocyte count (DLC) lymphocytes, monocytes and eosinophils register an increase but neutrophils, basophils and thrombocyte population exhibit a decline in their number. Cortisol and glucose levels were noticed to increase up to $4^{\text {th }}$ week and after that exhibit a declining trend in their values during the rest period $\left(5^{\text {th }}-9^{\text {th }}\right.$ week) of experimental duration.
\end{abstract}

A B S T R A C T

Studies on stress in different species of fish has been widely made but not much has been done in hill stream fishes especially, Garra gotyla gotyla. Haematological and hormonal parameters are the most common stress indicators. In the present study, an attempt has

\section{Introduction}

Stress can be described as the physiological response to a stressor. In other words, stress is an internal physiological state that is caused by external conditions. Stress can also be described as an internal hormonal response of a living organism caused by environmental or other external factors that moves that organism out of its normal physiological resting state, or homeostasis (Selye, 1973). Stress can disturb the normal physiological equilibrium or homeostasis of fish by forcing a reallocation of energy within its system. Stress in fish, a key member of aquatic environment and which also form a valuable commodity for human consumption (proteins, 16-23\%) may be induced by various abiotic 
environmental factors (change in water temperature, $\mathrm{pH}, \mathrm{O}_{2}$ concentrations, starvation etc) (Gupta, 2009; Raina, 2011). Besides these natural stressors, heavy metals and xenobiotics (anthropogenic stressors) are regarded as the serious pollutants which act as major source of stress to fishes (Tavares-Dias and Barcellos, 2005) which find their entry into waterbodies through industrial, domestic and agricultural discharge system. All these natural and anthropogenic stressors disturb the homeostatic mechanism of fishes besides creating considerable stress to fishes (Vosyliene and Kazlauskiene, 1999).

Fish respond to chemicals and other stressors at intensity levels that are often far below those that can be detected by terrestrial animals (Wendelaar Bonga, 1997). Fish are more sensitive to stressors than many other vertebrates because their physiological homeostasis is intimately bound to and dependent upon the water in the surrounding environment. Disturbance of water and ion homeostasis during stress is due to the very intimate relationship between body fluids in the gills and the ambient water.

Physiological responses of fish to environmental stressors have been grouped broadly as primary and secondary. Primary responses, which involve the initial neuroendocrines, include the release of catecholamines from chromaffin tissue (Randall and Perry, 1992; Reid et al., 1998) and the stimulation of the hypothalamicpituitary-interrenal (HPI) axis culminating in the release of corticosteroid hormones into circulation (Donaldson, 1981; Wendelaar Bonga, 1997; Mommsen et al., 1999 and Martinez-Porchas et al., 2009). Secondary responses include changes in plasma and tissue ions and metabolite levels, haematological features, and heat-shock or stress proteins (HSPs), all of which relate to physiological adjustments such as metabolism, respiration, acid-base status, hydromineral balance, immune function and cellular responses (Pickering, 1981; Iwama et al., 1997 and Gupta et al., 2012). Additionally, tertiary responses occur which refer to aspects of whole-animal performance such as changes in growth condition, overall resistance to disease, metabolic scope for activity, behaviour, and ultimately survival (Wedemeyer et al., 1990; Martinez-Porchas et al., 2009 and Gupta et al., 2012). Depending on its magnitude and duration, stress may affect fish at all levels of organization, from molecular and biochemical to population and community (Adams, 1990).

Haematological evaluation of fish provides valuable facts concerning the physiological response of fish to changes in the external environment. Study of haematological parameters on one hand help in establishing the health status of fish and on other is the cheapest, trusted and well known tool to monitor the ambient aquatic environment of the fish (Allen, 1994; Buthelezi et al., 2000 and Raina, 2011). Blood is a sensitive indicator of stress and any physiological dysfunctioning in fish's body get reflected as alterations in its blood constituents.

Blood being the medium of intercellular and intracellular transport, comes in contact with various organs and tissues of the body and thus can pose a direct threat to physiological functions of the fish. Xenobiotics (like heavy metals/ pesticides) rapidly bind to the blood proteins and thus may induce haematological changes on one hand and histopathological on the other.

In fishes like mammals, the glucocorticoids are important in regulating a number of functions that enable them to respond to stress and to resist stressors (Munch et al., 1984). Glucocorticoid steroid hormones regulate the production and functioning of a great many 
proteins and are important not only in regulation of homeostatic functions like metabolism and osmoregulation but also in their capacity to affect immune functions. Stress has been reported to elevate plasma cortisol which is one of important glucocorticoid (Pottinger and Mosuwe, 1994; Wendelaar Bonga, 1997; Pottinger et al., 2003 and Haukenes et al., 2008) and many researchers consider it as a "rule of thumb" that fishes undergoing stressful situations exhibit plasmatic increase in cortisol levels. Cortisol not only activates glycogenolysis and gluconeogenesis in fish but also activates the chromaffin cells to increase the release of catecholamines which further increase glycogenolysis and modulate cardiovascular and respiratory function (Reid et al., 1992, 1998). This whole process increases the substrate levels (glucose) to produce enough energy as per the demand and thus prepare the fish for an emergency situation (Rottmann et al., 1992 and Gupta et al., 2012).

Presently, therefore a study has been undertaken to evaluate the effect of stressors both natural (Starvation) and anthropogenic (Manganese) on haematological and hormonal parameters of fish Garra gotyla gotyla for a period of 9 weeks.

\section{Materials and Methods}

Garra gotyla gotyla were collected with the help of cast net from the Jhajjar stream of Jhajjar Kotli region of Jammu, J\&K, India. After acclimatization, the 96hours $\mathrm{LC}_{50}$ value of $\mathrm{MnSO}_{4}$ was determined as $3.2 \mathrm{mg} / \mathrm{l}$. One group of fish was exposed to $60 \%$ sublethal concentration of $\mathrm{MnSO}_{4}(1.96 \mathrm{mg} / \mathrm{l})$ and other group was starved for a period of 9 weeks. The haematological parameters viz. TEC, Hb, Hct, TLC and DLC and cortisol and glucose levels of control and stressed (starved and metal treated) fishes were studied by collecting blood samples with the help of disposable insulin syringes by making an incision through the heart of fish. TEC and TLC were counted with the help of improved Neubauer haemocytometer (Maule and Schreck, 1990). DLC was counted by methodology adopted by Anderson (2003). $\mathrm{Hb}$ was estimated by using Sahlis haemoglobinometer (Dethloff et al., 1999). Hct was determined by centrifugation method (Wintrobe, 1967). For the estimation of cortisol and glucose blood was collected in plastic Eppendrof tubes. After centrifugation, blood plasma was removed and the samples were then analyzed for measuring the levels of cortisol by Radioimmunoassay following the methodology adopted by Tort et al., (1998). Glucose was estimated following the methodology followed by Correl and Langley (1956).The results obtained were analyzed statistically by one way analysis of variance (ANOVA) by SPSS software for determining the significance of change from control.

\section{Results and Discussion}

Compared to control groups, starved fishes were found to exhibit significant decline $(\mathrm{P}<0.01)$ in TEC, Hb, Hct and TLC. DLC depicted decrease in lymphocytes, monocytes, eosinophils and basophils whereas neutrophils and thrombocytes rather exhibited an increment in their number (Table 1and Figure 1e-f). A significant increase $(\mathrm{P}<0.01)$ in cortisol and glucose levels were observed upto $5^{\text {th }}$ week and after that a decline was observed in their values from $6^{\text {th }}$ to $9^{\text {th }}$ week (Table 1). Manganese treated fishes showed significant decline $(\mathrm{P}<0.01)$ in $\mathrm{TEC}, \mathrm{Hb}$ and Hct while TLC depicted significant increase. Lymphocytes, monocytes and eosinophils register an increase in their population but neutrophils, basophils and thrombocyte population depicted decrease in their population (Table 2 and Figure 2c-f). Cortisol and glucose levels were noticed to increase upto $4^{\text {th }}$ week and after that exhibit a declining trend in their values during the rest period $\left(5^{\text {th }}-9^{\text {th }}\right.$ week $)$ of experimental duration 
(Table 2). Comparison of data of controls with that of starved and manganese treated groups very clearly indicates that there is a marked decline in TEC, $\mathrm{Hb}$ and Hct at the end of experimental period in both starved and manganese treated fishes (Tables 1 and 2). Similar to present findings, Jenkin and Smith et al., (2003), Tyagi and Srivastva (2005), Gupta (2008), Gupta et al., (2009), Raina (2011), Sachar (2011) and Gupta (2012) have also reported declining trend in TEC, $\mathrm{Hb}$ and Hct of fishes following subjection to starvation and different metals.

Present authors propose that starvation and metal toxicity results in decreased rate of erythropoises in haemopoietic organs and senescence in pre-existent cells of blood stream. Moreover there was no or null replacement of these cells by new ones for want of availability of nutrients under prevailing condition of starvation and due to toxic effects of metal (Figures 1c-f and 2c-f). Present viewpoint get an added support from the work of Santhakumar et al., (2000), Gupta et al., (2009) and Gupta (2012) who also have observed similar observations/results under the prevailing condition of starvation and metal toxicity.

Presently, besides affecting erythrocyte number (Tables 1 and 2) starvation and metal toxicity has also been found to result in marked anomalies in shape of RBCs as well as nucleus compared to that of control (Figures 1(a-f) and 2(a-f)). The distorted RBCs which make their appearance during the $1^{\text {st }}$ week (metal treated) and $2^{\text {nd }}$ week (starvation) of experimental period in very few number register an increase with the advancement of experiment indicating clearly that TEC not only decline quantitatively but qualitatively also (Figures 1c, 1d, 2d and e). Distorted/ abnormal shape of RBCs can lead to tissue hypoxia by reducing the oxygen carrying capacity of RBCs and same has also been earlier reported by workers viz. Das
(1998), Yang and Chen (2003) and Verma (2007). These morphological changes in erythrocytes initiate the process of $\mathrm{RBC}$ destruction and ultimately lead to their complete degeneration.

In tune with $\mathrm{TEC}, \mathrm{Hb}$ and Hct also exhibited a significant decrement $(\mathrm{P}<0.01)$ in their values following an exposure to starvation and metal toxicity. The possible reason for decline in $\mathrm{Hb}$ and Hct, according to present author, seemingly appears to be because of decline in the number of normal RBCs and the null replacement of deformed cells by normal ones. Similar to present findings Rios et al., (2005), Gupta (2009) and Raina (2011) also reported decline in normal RBCs as a major factor contributing in declining of $\mathrm{Hb}$ and Hct in starved and metal treated fishes.

White blood cells or leucocytes are the cells of immune system which defend the body of organism against infectious as well as foreign materials. Review of literature reveals that there are two schools of thought regarding the response of leucocytes to various stressors and xenobiotics. According to workers of first school (Iwama et al., 1976; Mishra and Srivastava, 1979; Ellis, 1981; Sharma and Gupta, 1984 and Adeymo, 2007) there is a decrease in TLC whereas workers of second school viz. Torres et al., (1984), Garg et al., (1989), Singh and Tandon (2009) and Buthelizi et al., (2000) advocated increase in their number in response to stress of any kind. Presently our results are in accordance with first group of workers for starved group of fishes and to second group of workers for metal treated groups. The increase in TLC, as observed metal treated groups can be attributed to a stimulation of the immune system in response to tissue damage caused by manganese whereas in starved fishes stress of starvation result by deficient nourishment leads to weakening of immune system and hence in decrement in number of leucocytes. 
Int.J.Curr.Microbiol.App.Sci (2017) 6(5): 357-369

Table.1 Effect of starvation on haematological and hormonal parameters of Garra gotyla gotyla

\begin{tabular}{|c|c|c|c|c|c|c|c|c|c|c|c|c|}
\hline $\begin{array}{c}\text { Time } \\
\text { Interval }\end{array}$ & $\begin{array}{l}\text { TEC } \\
\left(\times 10^{6} / \mathrm{cmm}\right)\end{array}$ & $\begin{array}{l}\mathrm{Hb} \\
(\%)\end{array}$ & $\begin{array}{l}\text { Het } \\
(\%)\end{array}$ & $\begin{array}{l}\text { TLC } \\
\left(\times 10^{3} / \mathrm{cmm}\right)\end{array}$ & $\begin{array}{l}\text { Lymphocyte } \\
\%\end{array}$ & $\begin{array}{l}\text { Neutrophil } \\
\%\end{array}$ & $\begin{array}{l}\text { Monocyte } \\
\%\end{array}$ & $\begin{array}{l}\text { Basophil } \\
\%\end{array}$ & $\begin{array}{l}\text { Eosinophil } \\
\%\end{array}$ & $\begin{array}{l}\text { Thrombocyte } \\
\%\end{array}$ & $\begin{array}{l}\text { Cortisol } \\
\text { (ng/ml) }\end{array}$ & $\begin{array}{l}\text { Glucose } \\
\text { (mg/dl) }\end{array}$ \\
\hline Control & $2.68 \pm 0.25$ & $8.4 \pm 0.21$ & $41.7 \pm 0.10$ & $13.96 \pm 0.24$ & $40.2 \pm 0.02$ & $24.2 \pm 0.41$ & $4.3 \pm 0.22$ & $1.5 \pm 0.25$ & $1.2 \pm 0.29$ & $28.6 \pm 0.14$ & $115.0 \pm 0.84$ & $78.6 \pm 0.25$ \\
\hline $1^{\text {st }} \mathbf{w k}$ & $2.62 \pm 0.14$ & $8.2 \pm 0.52$ & $41.2 \pm 0.43$ & $13.42 \pm 0.53$ & $38.8 \pm 0.16$ & $25.6 \pm 0.30$ & $4.1 \pm 0.16$ & $1.4 \pm 0.39$ & $1.1 \pm 0.36$ & $29.0 \pm 0.35$ & $125.5 \pm 0.25$ & $90.5 \pm 0.19$ \\
\hline $2^{\text {nd }} w k$ & $2.48 \pm 0.64$ & $7.9 \pm 0.18$ & $39.7 \pm 0.58$ & $13.05 \pm 0.19$ & $35.2 \pm 0.38$ & $27.4 \pm 0.26$ & $3.8 \pm 0.38$ & $1.2 \pm 0.07$ & $1.0 \pm 0.02$ & $31.4 \pm 0.25$ & $138.0 \pm 1.20$ & $106.3 \pm 0.34$ \\
\hline $3^{\text {rd }} w k$ & $2.23 \pm 0.71$ & $7.5 \pm 0.57$ & $38.0 \pm 0.62$ & $12.69 \pm 0.47$ & $34.3 \pm 0.12$ & $27.6 \pm 0.04$ & $3.7 \pm 0.14$ & $1.0 \pm 0.18$ & $0.9 \pm 0.18$ & $32.5 \pm 0.17$ & $146.5 \pm 0.38$ & $125.4 \pm 0.16$ \\
\hline $4^{\text {th }}$ wk & $2.02 \pm 0.26$ & $7.0 \pm 0.83$ & $36.5 \pm 0.41$ & $12.34 \pm 0.33$ & $31.7 \pm 0.37$ & $29.8 \pm 0.50$ & $3.5 \pm 0.69$ & $0.9 \pm 0.69$ & $0.7 \pm 0.33$ & $33.4 \pm 0.19$ & $175.2 \pm 1.54$ & $155.2 \pm 1.24$ \\
\hline $5^{\text {th }} w k$ & $1.85 \pm 0.05$ & $6.5 \pm 0.23$ & $34.0 \pm 0.86$ & $12.08 \pm 0.64$ & $29.4 \pm 0.62$ & $31.4 \pm 0.19$ & $3.1 \pm 0.17$ & $0.7 \pm 0.18$ & $0.5 \pm 0.12$ & $34.9 \pm 0.14$ & $210.5 \pm 0.86$ & $180.0 \pm 1.05$ \\
\hline $6^{\text {th }}$ wk & $1.62 \pm 0.63$ & $6.2 \pm 0.43$ & $33.5 \pm 0.36$ & $11.72 \pm 0.99$ & $26.9 \pm 0.14$ & $33.8 \pm 0.18$ & $2.9 \pm 0.37$ & $0.6 \pm 0.55$ & $0.4 \pm 0.43$ & $35.4 \pm 0.36$ & $172.0 \pm 0.46$ & $158.0 \pm 1.42$ \\
\hline $7^{\text {th }}$ wk & $1.55 \pm 0.19$ & $5.8 \pm 0.38$ & $32.4 \pm 0.14$ & $11.37 \pm 0.12$ & $24.5 \pm 0.29$ & $34.9 \pm 0.34$ & $2.5 \pm 0.19$ & $0.6 \pm 0.59$ & $0.3 \pm 0.73$ & $37.2 \pm 0.25$ & $158.3 \pm 1.24$ & $135.3 \pm 0.36$ \\
\hline $8^{\text {th }}$ wk & $1.48 \pm 0.47$ & $5.5 \pm 0.61$ & $31.2 \pm 0.57$ & $11.11 \pm 0.34$ & $23.3 \pm 0.81$ & $35.7 \pm 0.17$ & $2.2 \pm 0.34$ & $0.3 \pm 0.85$ & $0.2 \pm 0.15$ & $38.3 \pm 0.10$ & $140.0 \pm 0.78$ & $120.5 \pm 1.15$ \\
\hline $9^{\text {th }}$ wk & $1.40 \pm 0.35$ & $5.3 \pm 0.49$ & $30.0 \pm 0.19$ & $10.68 \pm 0.27$ & $21.6 \pm 0.16$ & $35.8 \pm 0.44$ & $1.9 \pm 0.12$ & $0.1 \pm 0.47$ & $0.2 \pm 0.66$ & $40.4 \pm 0.38$ & $124.5 \pm 0.69$ & $114.8 \pm 0.64$ \\
\hline
\end{tabular}




\section{Int.J.Curr.Microbiol.App.Sci (2017) 6(5): 357-369}

Table.2 Effect of manganese toxicity on haematological and hormonal parameters of fish Garra gotyla gotyla

\begin{tabular}{|c|c|c|c|c|c|c|c|c|c|c|c|c|}
\hline $\begin{array}{l}\text { Time } \\
\text { Interval }\end{array}$ & $\begin{array}{l}\text { TEC }\left(\times 10^{6} \%\right. \\
\mathrm{cmm})\end{array}$ & $\begin{array}{l}\mathrm{Hb} \\
(\%)\end{array}$ & $\begin{array}{l}\text { Het } \\
(\%)\end{array}$ & $\begin{array}{l}\text { TLC } \\
\left(\times 10^{3} / \mathrm{cmm}\right)\end{array}$ & $\begin{array}{l}\text { Lymphocyte } \\
\%\end{array}$ & $\begin{array}{l}\text { Neutrophil } \\
\%\end{array}$ & $\begin{array}{l}\text { Monocyte } \\
\%\end{array}$ & $\begin{array}{l}\text { Basophil } \\
\%\end{array}$ & $\begin{array}{l}\text { Eosinophil } \\
\%\end{array}$ & $\begin{array}{l}\text { Thrombocyte } \\
\%\end{array}$ & $\begin{array}{l}\text { Cortisol } \\
\text { (ng/ml) }\end{array}$ & $\begin{array}{l}\text { Glucose } \\
\text { (mg/dl) }\end{array}$ \\
\hline Control & $2.72 \pm 0.24$ & $8.5 \pm 0.33$ & $42.5 \pm 0.20$ & $12.34 \pm 0.26$ & $40.2 \pm 0.63$ & $28.4 \pm 0.35$ & $4.1 \pm 0.17$ & $1.7 \pm 0.19$ & $0.1 \pm 0.54$ & $25.5 \pm 0.56$ & $109.8 \pm 0.82$ & $82.5 \pm 0.24$ \\
\hline $1^{\text {st }} w k$ & $2.47 \pm 0.12$ & $7.6 \pm 0.55$ & $39.5 \pm 0.21$ & $12.67 \pm 0.15$ & $42.4 \pm 0.0 .54$ & $26.8 \pm 0.22$ & $4.2 \pm 0.12$ & $1.4 \pm 0.26$ & $0.1 \pm 0.22$ & $25.1 \pm 0.38$ & $230.0 \pm 0.13$ & $205.0 \pm 0.06$ \\
\hline $2^{\text {nd }} w k$ & $2.32 \pm 0.05$ & $7.3 \pm 0.19$ & $38.6 \pm 0.38$ & $12.99 \pm 0.24$ & $43.6 \pm 0.24$ & $25.8 \pm 0.39$ & $4.5 \pm 0.35$ & $1.2 \pm 0.16$ & $0.2 \pm 0.37$ & $24.7 \pm 0.38$ & $232.0 \pm 1.69$ & $215.2 \pm 1.95$ \\
\hline $3^{\text {rd }}$ wk & $2.19 \pm 0.68$ & $7.0 \pm 0.37$ & $35.9 \pm 0.14$ & $13.32 \pm 0.39$ & $44.4 \pm 0.38$ & $25.3 \pm 0.48$ & $4.9 \pm 0.18$ & $1.1 \pm 0.39$ & $0.3 \pm 0.92$ & $24.0 \pm 0.48$ & $234.5 \pm 1.98$ & $219.6 \pm 1.47$ \\
\hline $4^{\text {th }} \mathrm{wk}$ & $2.08 \pm 0.49$ & $6.8 \pm 0.46$ & $34.2 \pm 0.39$ & $13.84 \pm 0.55$ & $45.3 \pm 0.47$ & $24.6 \pm 0.59$ & $5.3 \pm 0.46$ & $0.9 \pm 0.48$ & $0.5 \pm 0.83$ & $23.4 \pm 0.22$ & $240.0 \pm 0.38$ & $224.2 \pm 0.39$ \\
\hline $5^{\text {th }}$ wk & $1.88 \pm 0.19$ & $6.4 \pm 0.18$ & $32.3 \pm 0.54$ & $14.46 \pm 0.14$ & $46.7 \pm 0.21$ & $23.7 \pm 0.43$ & $5.5 \pm 0.19$ & $0.7 \pm 0.28$ & $0.8 \pm 0.38$ & $22.6 \pm 0.18$ & $160.0 \pm 0.09$ & $175.0 \pm 0.54$ \\
\hline $6^{\text {th }}$ wk & $1.76 \pm 0.38$ & $6.3 \pm 0.39$ & $29.9 \pm 0.36$ & $14.92 \pm 0.69$ & $48.7 \pm 0.69$ & $22.5 \pm 0.88$ & $5.7 \pm 0.17$ & $0.6 \pm 0.37$ & $1.0 \pm 0.24$ & $21.5 \pm 0.38$ & $152.2 \pm 2.97$ & $152.6 \pm 1.22$ \\
\hline $7^{\text {th }}$ wk & $1.63 \pm 0.48$ & $5.9 \pm 0.86$ & $28.6 \pm 0.16$ & $15.38 \pm 0.83$ & $50.6 \pm 0.48$ & $21.6 \pm 0.28$ & $6.1 \pm 0.39$ & $0.5 \pm 0.19$ & $1.2 \pm 0.38$ & $20.0 \pm 0.47$ & $144.0 \pm 2.30$ & $134.0 \pm 0.08$ \\
\hline $8^{\text {th }}$ wk & $1.42 \pm 0.84$ & $5.7 \pm 0.02$ & $25.7 \pm 0.59$ & $15.80 \pm 0.28$ & $52.6 \pm 0.19$ & $20.4 \pm 0.18$ & $6.5 \pm 0.48$ & $0.2 \pm 0.33$ & $1.4 \pm 0.18$ & $18.9 \pm 0.33$ & $135.0 \pm 1.68$ & $126.5 \pm 1.25$ \\
\hline $9^{\text {th }}$ wk & $1.27 \pm 0.74$ & $5.2 \pm 0.67$ & $24.8 \pm 0.46$ & $16.35 \pm 0.19$ & $55.8 \pm 0.39$ & $17.3 \pm 0.14$ & $6.9 \pm 0.80$ & $0.1 \pm 0.61$ & $1.7 \pm 0.18$ & $18.2 \pm 0.29$ & $125.0 \pm 0.22$ & $102.5 \pm 0.56$ \\
\hline
\end{tabular}


Fig.1(a) Microphotograph of blood smear of control Garra gotyla gotyla showing erythrocytes (E), neutrophil (N), monocytes (Mo) and thrombocytes (Th) (100x); (b)Microphotograph of blood smear of control Garra gotyla gotyla showing erythrocytes (E), lymphocytes (L), basophils (B) and eosinophils (Eo) (100x); (c) Microphotograph of blood smear of starved Garra gotyla gotyla showing distorted erythrocytes (DE) after $3^{\text {rd }}$ week of the experiment (100x); (d) Microphotograph of blood smear of starved Garra gotyla gotyla showing distorted erythrocytes (DE) with distorted nucleus (DN) and vacuolated erythrocytes (VE) after $5^{\text {th }}$ week of the experiment (100x); (e) Microphotograph of blood smear of starved Garra gotyla gotyla showing vacuolated erythrocytes (VE), distorted erythrocytes (DE) and increase in neutrophils (N) and thrombocytes (Th) after $8^{\text {th }}$ week of the experiment (100x); (f) Microphotograph of blood smear of starved Garra gotyla showing increase in vacuolated erythrocytes (VE) and marked decrease in lymphocytes (L) and basophils (B) after $9^{\text {th }}$ week of the experiment $(100 \mathrm{x})$

(a)

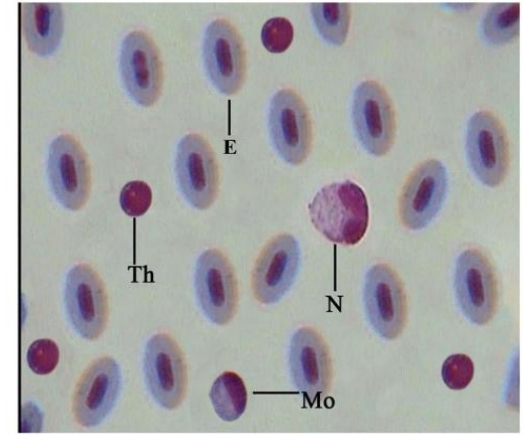

(c)

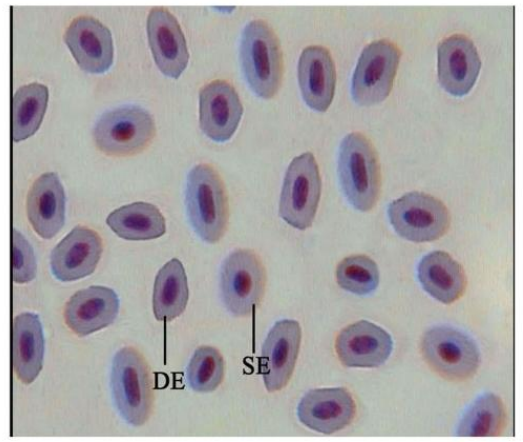

(e)

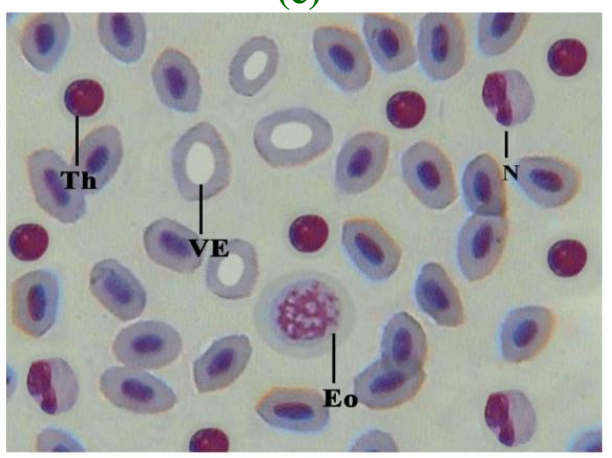

(b)

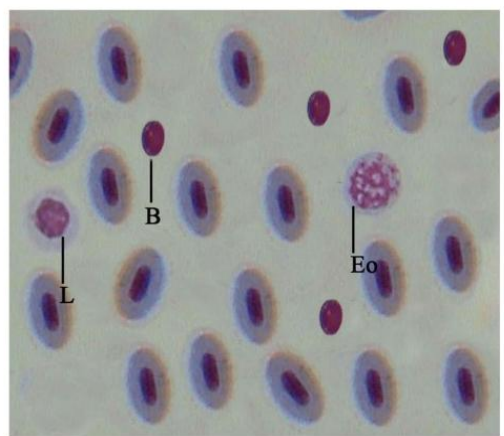

(d)

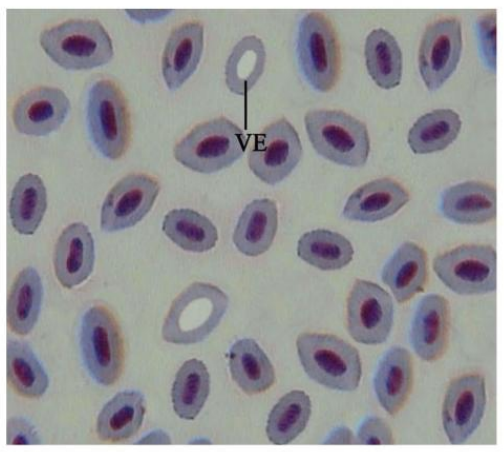

(f)

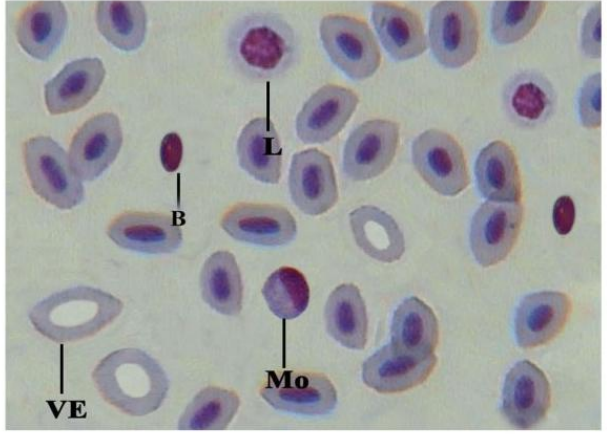


Fig.2(a) Microphotograph of blood smear of control Garra gotyla gotyla showing erythrocytes (E), neutrophils (N), lymphocytes (L) and thrombocytes (Th) (100x); (b) Microphotograph of blood smear of control Garra gotyla gotyla showing basophils (B), eosinophils (Eo) and monocytes (M) (100x); (c) Microphotograph of blood smear of Garra gotyla gotyla treated with manganese showing increase in lymphocytes (L) and eosinophils (Eo) and decrease in neutrophils (N) after $1^{\text {st }}$ week of the experiment (100x); (d) Microphotograph of blood smear of Garra gotyla gotyla treated with manganese showing distorted erythrocytes (DE) with distorted nucleus (DN) after $1^{\text {st }}$ week of the experiment (100x); (e) Microphotograph of blood smear of Garra gotyla gotyla treated with manganese showing swelled erythrocytes (SE) and deformed erythrocytes (DE) after $5^{\text {th }}$ week of the experiment (100x); (f) Microphotograph of blood smear of Garra gotyla gotyla treated with manganese showing marked increase in lymphocytes and monocytes and decrease in thrombocytes after $9^{\text {th }}$ week of the experiment $(100 x)$

(a)

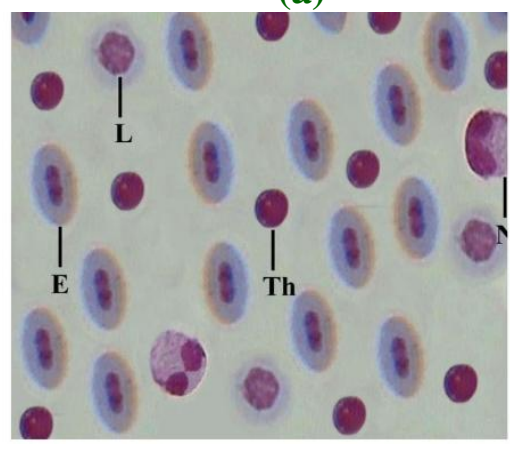

(c)

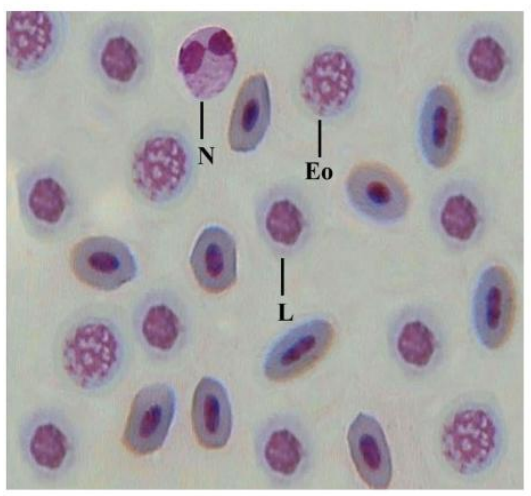

(e)

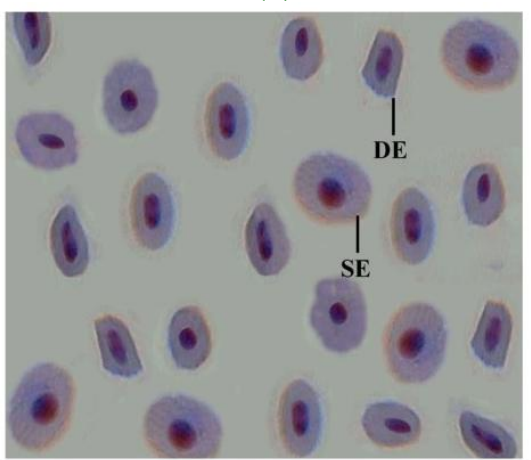

(b)

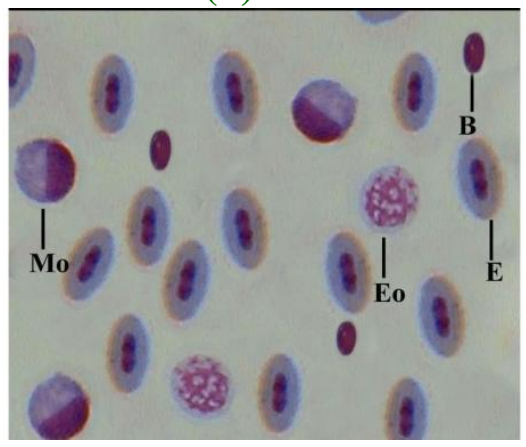

(d)

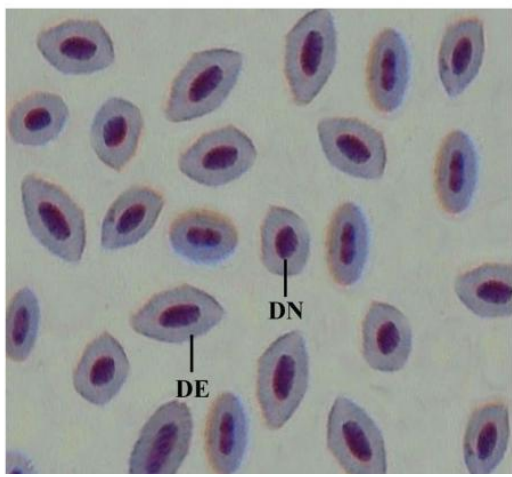

(f)

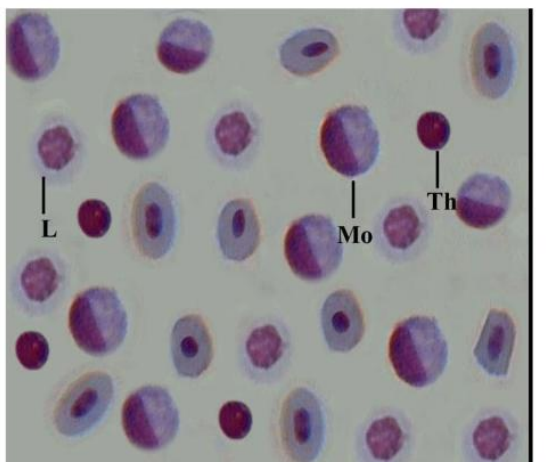


In depth study of the DLC (Table 1) further reveals that decrease in TLC in starved fishes can be an outcome of increase in neutrophils and thrombocytes and decrease in monocytes, eosinophils and basophils whereas increase in TLC upon manganese exposure can be very safely attributed to an increase in lymphocytes, monocytes and eosinophils. Neutrophils, basophils and thrombocytes however, have been observed to witness a decline in their number (Table 2).

Lymphocytes being important component of DLC help the fish to fight against infection by producing antibodies (Klesius et al., 1999). Decrease observed in lymphocyte number in starved fishes may result in decreased antibody production due to inhibitory response while increased availability of lymphocytes under metal intoxication possibly results in increased antibody production due to stimulatory response of lymphocytes. Such inhibitory and stimulatory responses of lymphocytes have also been reported by Gill and Pant (1985), Adewoye (2010) and Gupta (2012) against number of natural and anthropogenic stressors. Further increase observed in neutrophils and thrombocytes (starved fishes) and in monocytes and eosinophils (metal treated) may be in view of the fact that monocytes, eosinophils and basophils (starved fishes) and neutrophils, basophils and thrombocytes (metal treated) which too are the other members of phagocytic machinery in starved and metal treated groups show a dip under the stress of starvation and metal toxicity. Mahajan and Dheer (1979), Ishikawa et al., (2007) and Devi et al., (2008) also reported such changes in number of agranulocytes and granulocytes under the stress of starvation and metal toxicity.

It is on record (Barton, 1997 and MartinezPorchas et al., 2009) that cortisol hormone secreted, as primary response under the stress in fishes activates the process of glycogenolysis and gluconeogenesis to release more and more glucose in general circulation. This has been held as a secondary response in fish under the stress by Barton (1997) and Begg and Pankhrust (2004). Glucose so produced by making available greater supply of energy to fish help them to tide over the stress induced by starvation and metal toxicity (Rottmann et al., 1992). Presently too, in line with above, elevated levels of cortisol has been observed simultaneously to result in the increased levels of serum glucose (Tables 1 and 2) in Garra gotyla gotyla. Thus observed increase in serum cortisol level may plausibly be ascribed to starvation and metal toxicity related hyperglycemic condition in all stressed fishes.

Review of literature further reveals that there is limit up to which cortisol can be secreted by hypothalamus pituitary interrenal axis in fishes during acute response (Dickhoff, 1989 and Martinez-Porchas et al., 2009). This limit varies in different fishes depending on their age, maturity, species, duration of stress etc. After attaining this limit, the cortisol level of fishes, all of the above workers held return to basal levels to avoid tissue damage. Such damage has also been observed by Dickhoff (1989) and Stein-Behrun and Sapolsky (1992) in salmons, where high levels of cortisol was observed to cause death in Pacific salmon (Onchorhynchus sps.) by tissue degeneration and damage of homeostatic mechanism. Interestingly although no fish mortality has been observed during the entire experimental period of nine weeks but increase in cortisol reached peak/ highest level only up to $5^{\text {th }}$ week in starved and $4^{\text {th }}$ week in metal treated fishes and thereafter though cortisol still was higher than controls but could never cross the peak level. Rather, the extent of increase now revealed a declining trend. 
The possible reason for decline observed in the values of cortisol in both starved and metal treated groups is that hypothalamus pituitary interrenal axis (HPI), a system responsible for secretion of cortisol get exhausted due to stress of starvation and metal toxicity by causing down regulation of this system through negative feedback in fish Garra gotyla gotyla. In consonance with present viewpoint, Barton et al., (2005) and Fast et al., (2008) also reported exhaustion of endocrine system in stressed fishes to be the possibly causative of decline in titre of cortisol after exhibiting an initial peak.

On the basis of foregoing discussion it can be safely deduced that stressor of any kind natural or anthropogenic affect the haematological and hormonal balance in fish and by affecting these systems result in deterioration of fish quality which can have detrimental effects on human health.

Such studies therefore, all the more become important as these may help by making us knowledgeable as to how different fish species (presently Garra gotyla gotyla) become highly resistant/ tolerant to survive under stressful conditions of starvation and metal toxicity. Such conditions exist frequently in natural environment of plains, in general and hilly area (presently) in particular.

Such studies have far reaching effects, not only on the quality fish production but also on its progeny, and moreover appear to be of great help, particularly to the fish farmers in working out the appropriate food regimes and physic-chemical properties in the establishment of culture practice for different fish species of hilly region.

\section{References}

Adewoye, S.O. 2010. Haematological and biochemical changes in Clarias gariepinus exposed to Trephosita vogelii extract. Adv. Appl. Sci. Res., 1(1): 74-79.

Adeyemo, O.K. 2007. Haematological profile of Clarias gariepinus (Burchell, 1822) exposed to lead. Turkish J. Fisheries and Aquatic Sci., 7: 163-169.

Allen, P. 1994. Changes in the haematological profile of cichlid, Oreochromis auratus during acute inorganic mercury intoxication. Comp. Biochem. Physiol., 108C: 117-121.

Anderson, D.P. 2003. Text book of fish immunology, Narendra Publishing House, $1-177$.

Barton, B.A, Ribas, L., Acerete, L. and Tort, L. 2005. Effects of chronic confinement on physiological responses of the juvenile gilthead sea bream, Sparus aurata L. to acute handling. Aquaculture Res., 36: 172-179.

Barton, B.A. 1997. Stress in finfish: past, present and future - a historical perspective. In: Iwama, G. K., Pickering, A. D., Sumpter, J. P. and Schreck, C. B. eds. Fish Stress and Health in Aquaculture, pp. 1-33. Soc. Exp. Biol. Sem. Ser. 62, Cambridge Univ. Press, Cambridge, U.K.

Begg, K. and Pankhurst, N.W. 2004. Endocrine and metabolic responses to stress in a laboratory population of the tropical damselfish Acanthochromis polyacanthus. J. Fish Biol., 64: 133-145.

Buthelezi, P.P., Wepener, V. and Cyrus, D.P. 2000. The sublethal effect of zinc at different water temperatures on selected haematological variables in Oreochromis mossambicus. American J. Aquatic Sci., 25: 146-151.

Correl, N.V. and Langley, R.W. 1956. Glycogen determination in liver and muscle by use of anthrone reagent. $J$. Biol. Chem., 26: 583-593.

Das, B.K. 1998. Studies on the effect of some pesticide and commonly used chemicals on Indian major carps and their ecosystem. M.Phil. Thesis, Orissa University of Agriculture and Technology, Bhubaneshwar (India), 139162. 
Dethloff, G.M., Schlenk, D., Khan, S. and Bailey, H.C. 1999. The effects of copper on blood and biochemical parameters of rainbow trout (Oncorhynchus mykiss. Arch. Environ. Contam. Toxicol., 36: 415423.

Devi, P., Baruah, D., Baruh, B.K. and Borkotok, A. 2008. Impact of endosulphan on some haematological parameters of Channa punctatus (Bloch. Poll Res., 27(3): 485-488.

Dickhoff, W.W. 1989. Salmonids and annual fishes: Death after sex. In M. P. Schreibman and C. G. Scanes (eds.), Development, maturation, and senescence of neuroendocrine systems: A comparative approach, pp. 253-268. Academic Press, New York.

Donaldson, E.M. 1981. The pituitary-interrenal axis as an indicator of stress in fish. In: Stress and Fish (Pickering A. D., ed.. Academic Press, London and New York.

Ellis, A.E. 1981. Stress and the modulation of defense mechanism in fish. In: Stress and Fish Pickering AD (Ed). Academic Press, London, 3: 147-171.

Fast, M.D., Hosoya, S., Johnson, S.C. and Afonso, L.O.B. 2008. Cortisol response and immune-related effects of Atlantic salmon (Salmo salar Linnaeus) subjected to short- and long-term stress. Fish Shellfish, 24: 194-204.

Garg, V.K., Garg, S.K. and Tyagi, S.K. 1989. Manganese induced haematological and biochemical anomalies in Heteropneustes fossilis. J. Environ. Biol., 10(4): 349-353.

Gill, T.S. and Pant, J.C. 1985. Erythrocytic and leucocytic response to cadmium in fresh water fish Puntius conchonius. Environ. Res., 36: 327-335.

Gupta, K. 2008. Copper induced toxicity on haematological and haemopoietic profile of Puntius sophore (Ham). M. Phil. Thesis, University of Jammu, Jammu.

Gupta, K. 2012. Studies on effect of heavy metal toxicity on the histophysiology of blood and haemopoietic tissues of some fish species, Ph. D Thesis. University of Jammu.
Gupta, K., Langer, S., Sharma, J. and Sharma, S. 2012. Effect of different sublethal concentrations of Manganese on the levels of cortisol in Garra gotyla gotyla. Int. J. Scientific Res. Publications, 2(10): 1-3. ISSN 2250-3153.

Gupta, K., Sachar, A., Gupta, K. and Raina, S. 2009. Effect of lindane on haematological parameters of minor carp, Labeo boga (Ham). Biosci. Biotechnol. Res. Asia., 6(2): 695-702.

Gupta, R. 2009. Stress related haematological changes in Cyprinus carpio (Ham). M.Phil. Thesis, University of Jammu, Jammu.

Haukenes, A.H., Barton, B.A. and Bolligs, H. 2008. Cortisol responses of pallid sturgeon and yellow perch following challenge with lipopolysaccharide. J. Fish Biol., 72: 780-784.

Ishikawa, N.M., Ranzani-Paiva, M.J.T., Lombardi, J.V. and Ferreira, C.M. 2007. Haematological parameters in Nile Tilapia, Oreochromis niloticus exposed to sublethal concentrations of mercury. Braz. J. Zool., 50(4): 619-626.

Iwama, G.K., Greer, G.L. and Arkin, P.A. 1976. Changes in some haematological characteristics of Coho Salmon (Onchorhynchus kisutch) in response to acute exposure to dehydroabieticacid (DHAA) at different exposure levels. $J$. Fish Res. Board Can., 33: 285-289.

Iwama, G.K., Pickering, A.D., Sumpter, J.P. and Schreck, C.B. 1997. Fish stress and health in aquaculture. Cambridge Univ. Press, Cambridge, U.K. Soc. Exp. Biol. Sem. Ser., 62.

Jenkins, F., Smith, et al. 2003. Effect of sublethal concentration of endosulphan on haematological and serum biochemical parameters in the carp, C. carpio. Bull. Environ. Contam. Toxicol., 70: 993-947.

Klesius, P.H., Lim, C. and Shoemaker, C. 1999. Effect of feed deprivation on innate resistance and antibody response to Flavobacterium columnare in channel catfish, Ictalurus punctatus. Bull. European Association of Fish 
Pathologist, 19: 156-158.

Mahajan, C.L. and Dheer, J.M.S. $1979 b$. Seasonal variations in the blood constituents of an air breathing fish, Channa punctatus Bloch. J. Fish Biol., 14: 413-417.

Martinez-Porchas, M., Martinez-Cordova, L.R. and Ramos-Enriquez, R. 2009. Cortisol and Glucose: Reliable indicators of Fish Stress. Pan-American J. Aquatic Sci., 4(2): 158-178.

Martinez-Porchas, M., Martinez-Cordova, L.R. and Ramos-Enriquez, R. 2009. Cortisol and Glucose: Reliable indicators of Fish Stress. Pan-American J. Aquatic Sci., 4(2): 158-178.

Maule, A.G. and Schreck, C.B. 1990. Changes in the number of leucocytes in immune organs of juvenile coho after acute stress or cortisol treatment. J. Aquatic Animal Health, 2: 298-304.

Mishra, S. and Srivastava, A.K. 1979. Haematology as index of sublethal toxicity of zinc in a freshwater teleost. Bull. Environm. Contam. Toxicol., 22: 695-698.

Mommsen, T.P., Vijayan, M.M. and Moon, T.W. 1999. Cortisol in teleost: dynamics, mechanism of action, and metabolic regulation. Reviews on Fish Biol. Fisheries, 9: 211-268.

Munch, A., Guryre, P.M. and Holbrook, N.J. 1984. Physiological functions of glucocorticoids in stress and their relation to pharmacological actions. Endocr. Rev., 5(1): 25-44.

Pickering, A.D. 1981. Stress and fish. Academic Press, New York. http://icb.oxfordjournals.org/content/42/3/ 517.

Pottinger, T.G. 2003. The selection of trout for high and low responsiveness to stress: progress and prospects. Trout News, CEFAS, 36: 14-16.

Pottinger, T.G. and Mosuwe, E. 1994. The corticosteroidogenic response of brown and rainbow trout alevins and fry to environmental stress during a critical period. General and Comparative
Endocrinol., 95: 350-362.

Raina, S. 2011. Effect of environmental stress on haematology and immune organs of Labeo species. Ph. D thesis. University of Jammu, Jammu.

Randall, D.J. and Perry, S.F. 1992. Catecholamines. In: Hoar, W.S., Randall, D.J., Farrell, A.P. Eds., Fish PhysiologyThe Cardiovascular System, Vol. XIIB. Academic Press, New York. pp. 255-300.

Reid, S.D., Moon, T.W. and Perry, S.F. 1992. Rainbow trout hepatocyte betaadrenoceptors, catecholamine responsiveness, and effects of cortisol. American J. Physiol., 262: 794-799.

Reid, S.G., Bernier, N.J. and Perry, S.F. 1998. The adrenergic stress response in fish: control of catecholamine storage and release. Comparative Biochemi. Physiol., Part C, 120: 1-27.

Rios, F.S., Oba, E.T., Fernandes, M.N., Kalinin, A.L. and Ramtin, F.T. 2005. Erytrocytes senescence and haematoloical changes induced by starvation in the Neotropical fish traira, Hoplias malabaricus (Caraciformes, Erythrinidae. Comp. Biochem. Physiol., 140: 281-287.

Rottmann, R.W., Francis-Floyd, R. and Durborow, R. 1992. The role of stress in fish disease. SRAC Publication, 4: 474.

Sachar, A. 2011. Studies on effect of organic and inorganic pollutants on haematology, blood biochemistry and immune organs in some fishes of Jammu region. University of Jammu. Ph. D Thesis.

Santhakumara, M., Balaji, M. and Amudu, K. 2000. Adaptive changes in respiratory movements of an air breathing fish, Anabas testudineus exposed to organophosphate pesticide, monocroptophos. Eco. Env. Conserv. 6(1): 67-69.

Selye, H. 1973. The evolution of stress concept. Am. Sci., 61692-699.

Sharma, R.C. and Gupta, N. 1984. Carbontetrachloride induces haematological alterations in Clarias batrachus (L). J. Environ. Biol., 3: 127131. 
Singh, B.P. and Tandon, P.K. 2009. Effect of river pollution on haematological parameters of fish, Wallago attu. Res. Environ. Life Sci., 2(4): 211-214.

Stein-Behrens, B.A. and Sapolsky, R.M. 1992. Stress, glucocorticoids, and aging. Aging, 4: 197-210.

Tavares-Dias, M. and Barcellos, J.F.M. 2005. Peripheral blood cells of the armoredcatfish Hoplosternum littorale Hancock, 1828: a morphological and cytochemical study. Braz. J. Morphol. Sci., 22: 215 - 220.

Torres, P., Tort, L., Planas, J. and Flos, R. 1984. Effects of confinement stress and additional zinc treatment on some blood parameters in the dogdish (Scyliorhinus conicula. Comp. Biochem. Physiol., 83C: 89-92.

Tort, L., Padros, F., Rotllant, J. and Crespo, S. 1998. Winter syndrome in the gilthead sea bream Sparus aurata. Immunological and Histopathological features. Fish and Shellfish immunol., 8: 37-47.

Tyagi, A. and Srivastava, N. 2005. Haematological changes of fish Channa punctatus (Bloch) to chronic zinc exposure. J. Environ. Biol., 26(2): 429432.

Verma, G. 2007. Lindane (an insecticide) induced haematological changes in a minor carp, Puntius sophore (Ham). M. Phil. Thesis, University of Jammu, Jammu.

Vosyliene, M.Z. and Kazlauskiene, N. 1999. Alterations in fish health state parameters after exposure to different stressors. Acta Zoologica Hydrobiologica, 9(2): 13921657.

Vosyliene, M.Z., Kazlauskiene, N. and Svecevicius, G. 2003. Effect of heavy metal model mixture on biological parameters of rainbow trout Oncorhynchus mykiss. Environ. Sci. Pollut. Res., 10: 103-107.

Wedemeyer, G.A., Barton, B.A. and McLeay, D.J. 1990. Stress and acclimation In: Schreck, C.B., Moyle, P.B. Eds. Methods for Fish Biology. American Fisheries Society, Bathesda, MD., 451-489.

Wendelaar Bonga, S.E. 1997. The stress response in fish. Physiol. Rev., 77: 591625.

Wintrobe, M.M. 1967. "Clinical Haematology" VI ED., Philadelphia, Lea and Febiger.

Yang, J.L. and Chen, H.C. 2003. Effects of gallium on common carp (Cyprinus carpio): acute test, serum biochemistry and erythrocyte morphology. Chemosphere, 53: 877-882.

\section{How to cite this article:}

Jyoti Sharma, Shabir Ahmed Dar, A.N. Sayani and Seema Langer. 2017. Utilization of Mango Peel Powder (MPP) in Mango Nectar Formulation. Int.J.Curr.Microbiol.App.Sci. 6(5): 357-369. doi: http://dx.doi.org/10.20546/ijcmas.2017.605.041 